\title{
Toward Finding an Approach for Improving Rhetorical Organization of EFL Learners' Argumentative Writing
}

\author{
Toktam Miri \\ English Language Department, University of Guilan \\ Rasht, Iran \\ E-mail: t_miri61@yahoo.com
}

Received: 08-01-2014
doi:10.7575/aiac.ijalel.v.3n.3p.164
Published: 01-05-2014

\begin{abstract}
This study aimed at examining the probable impact of three distinct approaches to teaching writing, namely Process, Process-product and Product approaches on the rhetorical organization of EFL learners' argumentative essays. To fulfill this aim, after ensuring the homogeneity of the 45 participants of the study through Oxford Placement Test (OPT) the learners who were all at the intermediate level of English proficiency were divided into three groups comprising of 15 learners, each receiving instruction for 6 sessions based on the aforementioned approaches. After teaching the basic structure of an argumentative essay, the students in each group were required to write an essay in each session. In the last session they were asked to produce an essay which was considered as their post-test. The rhetorical organization of their writings was analyzed using a rubric adopted from the study of Tsai (2006). Using SPSS 16, the results of Oneway ANOVA at the alpha level of .05 revealed that there was a significant difference between those who wrote based on process approach and also process-product approach and those who were taught on the basis of product approach to writing. The pedagogical implications of the study are further discussed throughout the paper.
\end{abstract}

Keywords: EFL writing, product approach, process approach, process-product approach, rhetorical organization

\section{Introduction}

Compared with other language skills, writing is the most difficult skill for L2 learners. Language teachers and EFL practitioners have constantly been looking for an appropriate approach to make the task of writing less daunting for EFL learners. In this respect, several approaches to writing instruction have emerged in recent decades. Among the first proposed approaches to teaching writing has been "product approach" with its focus being mainly on grammatical and syntactic aspects of language with the primary aim of raising students' awareness of text patterns and formal accuracy of a piece of writing (Tangpermpoon, 2008). This approach was mainly teacher-centered and treated the development of writing competence as the result of learning and utilizing formal knowledge of language (Jarunthawatchai, 2010). Soon after, the product approach to writing instruction has been criticized as considering writing as a linear act and not taking into account the processes through which a text is generated, and also giving little attention to audience and the purposes for which we write.

As a reaction to the product approach, writing pedagogy was faced with a new approach which took into account the processes that the writers undergo to produce a text. This approach was named "process approach" to writing, and it viewed writing as a dynamic and recursive process (Tribble, 1990). Teachers implementing process approach in their writing classes made use of a series of activities to help students in generating ideas and drafting and revising them, thus this approach was more student-centered. However, as Badger and White (2000) pointed out process approach was also under criticism since it did not provide learners with a clear understanding about the characteristics of writing and provided the learners with insufficient input in its lack of a model.

As a way to compensate for the lacks in these approaches, scholars have proposed a mixed or integrated approach combining the merits of either product or process approaches to writing (e.g. Hyland, 2003). Accordingly, processproduct approach was emerged in the realm of writing pedagogy with the belief that this approach will enable EFL learners to transfer their knowledge and skills gained from each approach to the other one and perform better in their writing tasks.

In addition, Jarunthawatchai (2010) maintained that influenced by Kaplan's (1967) contrastive rhetoric, L2 practitioners came to understanding that writers should be aware of the organization of the texts. Thus, it is incumbent upon teachers to emphasize rhetorical rather than sentence level knowledge in their writing classes. Consequently, in typical classroom settings students can be guided to focus on rhetorical features of different genres. More specifically, since writing classes at university level mostly stress academic writing, attention should be due to the rhetorical organization of different essay types such as argumentative essays. 
Therefore, the present study aims at investigating the probable effect of three approaches to writing, namely Process, Process-product and Product approaches on the rhetorical organization of EFL learners' argumentative essays. To this end, this study addresses the following research question:

1- Is there any difference among the three instructional approaches to writing including process, process-product and product approaches with regard to their influence on the rhetorical organization of EFL learners' argumentative essays?

Regarding the aforementioned research question the following null hypothesis has been formulated:

$\mathrm{H}_{0} 1$. There is no difference among the three instructional approaches to writing including process, process-product and product approaches with regard to their influence on the rhetorical organization of EFL learners' argumentative essays.

\section{Theoretical and research background}

\subsection{Product Approach to Writing}

Gabrielatos (2002) defines product approach as "a traditional approach in which students are encouraged to mimic a model text, usually presented and analyzed at an early stage" (p.5; cited in Hassan \& Akhand, 2010).

As Tangpermpoon (2008) indicates, in the product approach students will start from pre-writing to composing to correcting. As a result, what is mostly emphasized in the product approach to writing is students' awareness in grammatical structures. Also, as Nunan (1999) states, in this approach the focal point is the final product which should be a coherent, error-free text and students will initiate, copy and transform models provided either by textbooks or by teachers. Furthermore, Steel (2004; cited in Hassan \& Akhand, 2010) describes four stages for the product approach to writing. In the first stage students will study a model text and then the important features of the genre are highlighted by the help of the teacher. In the second stage, students should practice those highlighted features usually in isolation. The third stage which is the most important one is when the ideas are organized and finally, in the fourth stage students will individually use the skills, structures and vocabulary they have been familiarized with to produce a written product to be later corrected by the teacher.

\subsection{Process Approach to Writing}

In process approach to writing the main focus is on the steps involved in producing a piece of work (Nunan, 1999). Its chief concern is to find out what writers do when they write, and how they come about with a written text. For this purpose, the focus is on different stages that the writers will go through for producing an essay or a composition. The notion of writing as process was firstly introduced to L2 studies by Vivian Zamel (1976), who argued for the similarity of advanced L2 writers to L1 writers and believed that L2 writers can benefit from the kind of instruction which emphasizes the process of writing. Accordingly, rather than viewing writing as a reproduction of syntactic or discourse structures which have been previously learned, the process-based approach views writing as a process of developing organization as well as promoting meaning. (Matsuda 2003, p. 21)

Moreover, O'Brian (2004, cited in Tangpermpoon, 2008) defines the concept of process approach as an activity in which writing is considered as the discovery of meaning and ideas. Schmitt (2002) also holds that the process approach regards the act of composing as a recursive, explanatory and generative process. In addition, Myles (2002) emphasized on the feedback stage of writing process by stating that the process approach to writing is only appropriate when learners have the opportunity to receive feedback on their written text. Therefore, process-based approach to writing, by providing an opportunity to learners to receive feedback either from other peers or from the teacher, allows students time to reflect upon and seek input as they reorganize their plans, ideas and search for the appropriate language to translate their ideas (Myles, 2002). Furthermore, Sutikno (2008) believes that the process approach to writing is more effective than the product approach, as it allows the student to explore and develop a kind of personal approach to writing. However, in spite of all the positive points about process approach to writing it suffers from lack of a good model, which as Torghabeh, Hashemi and Ahmadi (2010) truly mentioned, can partly eliminate the difficulty of devising content from the learners.

\subsection{Process-Product Approach to Writing}

The concept of process-product approach to writing is rather new and there are not so many scholars or teachers who have implemented it in their L2 writing classes. Brookes and Grundy (1990; cited in Tangpermpoon, 2008), claim that the teaching of writing through separate approaches will culminate in an unbalanced L2 writing performance. Accordingly, by integrating these approaches to writing, EFL learners are able to transfer the skills they have gained from each approach from one mode to another and have a better writing performance. Thus, in implementing the process-product approach in EFL writing classrooms, teachers can start with introducing a model essay to the learners with the aim of focusing on the rhetorical organization of the text. Then, they can engage the learners in different phases of the writing process including planning, drafting and revising.

Consequently, it can be suggested that by combining the merits of each of process or product approaches to writing teachers can make the task of writing easier for the students. One possible way of integration as Gholami Pasand and Bazarmaj Haghi (2013) suggested could be by teaching the rhetorical patterns of L2 writing to EFL learners by incorporating product approach to writing and combining it with different stages of process approach, and hence paying attention to the "hows" of writing. 
A vast amount of studies on the awareness of rhetorical organization of EFL learners' writing has been contrastive in nature. In other words, the researchers working in this area attempted to explore whether learners transfer their L1 rhetorical patterns while writing in L2. As such, there is scarcity of research on finding out a way to increase rhetorical awareness of learners while composing in L2. The challenges of accommodating L2 academic rhetorical patterns in learners' writing continue to be reported in the literature (Fishman \& McCarthy, 2001; Freedman, 1987, 1993; Kang, 2005). Moreover, $\mathrm{Mu}$ and Carrington (2007) state that, unlike other aspects of L1 writing, rhetorical strategies may not positively transfer to the L2. In what follows a few of the studies which are of a contrastive nature are reviewed.

Cheng and Chen (2009) conducted a study with the purpose of comparing the use of argumentative features based on Toulmin's (2003) model of argumentation among 40 Taiwanese and 39 American college students. The results indicated that Taiwanese students produced less complex and extended argumentative essays and exhibited a limited range of argumentative structures compared to the essays generated by American students. The study also demonstrated that when Taiwanese students wrote in Chinese, they were also able to employ certain argument features in a way similar to their American counterparts.

Khiabani and Pourghassemian (2009) examined the differences in the quality and organizational pattern of L1 versus L2 argumentative essays written by 120 Iranian EFL learners. The results did not show any significant difference between L1 and L2 argumentative writing of the participants with respect to the organizational patterns of their essays; however, it was revealed that students produced better quality L1 essays.

Finally, Zare-ee and Farvardin (2009) investigated the use of linguistic and rhetorical patterns of L1 and L2 argumentative writing produced by 30 Iranian EFL learners. They found a significant difference between students' essays written in L1 and L2 with regard to text length, complexity and writing organization. This study also like the other ones reviewed belonged to the contrastive rhetoric literature and did not address the impact of instructional approaches on EFL learners' use of argumentative structure as such.

\section{Research Method}

\subsection{Participants}

The present study was carried out at Guilan University in Rasht, Iran. 45 university students (12 males and 33 females) were randomly divided into three writing classes, each one receiving instruction based on distinct approaches to writing which included process, process-product, and product approaches. The students were all sophomores majoring in English Language and Literature. The writing classes for each group were held once a week for 90 minutes. The average age of the participants was 18 years old. The native language of all of the learners was Persian.

\subsection{Instruments}

The first instrument used in this study was Oxford Placement Test (OPT). Some argumentative essays were also used as a sample for students who were taught based on process-product and product approaches. Moreover, all the three groups were provided with some pamphlets for the purpose of becoming familiar with the argumentative genre of writing. Finally, we adopted a rubric from the study of Tsai (2006) and available in the appendix in order to analyze the rhetorical organization of students' argumentative essays. The rubric which is combination of Toulmin (1958) and McCann's (1989) model of argumentation consists of five major categories namely Claim, Data, Opposition, Refutation, and Qualifier.

\subsection{Procedure}

First, to ensure the homogeneity of the participants, OPT was administered to 45 students, and it was found that they are at the intermediate level of English language proficiency. Then the learners were randomly assigned to three groups each consisting of 15 students. After that, a One-Way ANOVA was run on the OPT scores of the three groups, and no significant difference in proficiency level was found among them.

In the second session students in each class were introduced to the argumentative genre of writing essays through lecturing. The students also received some model essays in order to have a better understanding of the genre. The next five weeks were spent on having the students in each group practicing writing argumentative essays using process approach, process-product approach, and product approach to writing.

The students who wrote based on process approach to writing went through different stages of "planning, drafting, revising, and editing" as described by Seow (2002; cited in Richards \& Renandya, 2002). To put it more specifically, in this class writing was considered as a spiral process and the focus was mostly on writing and re-writing in order to achieve a satisfactory result. Actually, the initial planning and discussion among students and the teacher helped writers to generate ideas more easily and this, in turn, reduced the burden of deciding what to write and how to organize their essays. Moreover, the students were provided by both peer and teacher feedback on the organization and content of their essays both during and at the end of each writing session.

The student in the product-process group went through the same stages of the writing process as was previously explained. However, there was a difference in this group in that before embarking on the act of writing, the learners were provided with a sample argumentative essay on the same topic that they were required to write about in that particular session. The model essay was analyzed through class discussion with the help of the teacher as a facilitator. The teacher with the help of the learners tried to highlight important sections of the model essay and explain about 
various ways of opposing or defending an idea. Then, the students were asked to go through the phases of writing process considering the analyzed model as a sample to draw on, at times. They also received both peer and teacher feedback during and after completing their essays.

Teaching procedure in the product group was in the traditional way of teaching writing. It started with handing a model essay to the learners and analyzing the main parts of the essay mostly through reading the text by the teacher and having students listen to it and the accompanying explanations. The teacher tried to focus on what should be written in each section of the essay including the thesis statement, pro ideas, con ideas, and conclusion. Then, the students were asked to produce an essay similar to the analyzed model. After submitting their essays to the teacher they were provided with the teacher feedback which mainly concentrated on the content and organization of their essays.

Finally, in the last session each student in all the three groups was required to write an argumentative essay to be used as their post-test.

\section{Results}

This section firstly illustrates results of the OPT, it then highlights the results of the analysis of the data as to the rhetorical organization of the stuents' argumentative essays. Table 1 shows the descriptive statistcs for the OPT.

Table 1. Descriptive statistics for OPT

\begin{tabular}{|c|c|c|c|c|c|c|c|c|}
\hline \multicolumn{9}{|l|}{ scores } \\
\hline & \multirow[t]{2}{*}{$\mathrm{N}$} & \multirow[t]{2}{*}{ Mean } & \multirow{2}{*}{$\begin{array}{c}\text { Std. } \\
\text { Deviatio } \\
\mathrm{n}\end{array}$} & \multirow[t]{2}{*}{$\begin{array}{l}\text { Std. } \\
\text { Error }\end{array}$} & \multicolumn{2}{|c|}{$\begin{array}{c}\text { 95\% Confidence Interval for } \\
\text { Mean }\end{array}$} & \multirow[t]{2}{*}{$\begin{array}{l}\text { Minimu } \\
\mathrm{m}\end{array}$} & \multirow[t]{2}{*}{$\begin{array}{l}\text { Maximu } \\
\mathrm{m}\end{array}$} \\
\hline & & & & & Lower Bound & Upper Bound & & \\
\hline Process & 15 & 3.800 & 6.358 & 1.64172 & 34.4789 & 41.5211 & 26.00 & 49.00 \\
\hline $\begin{array}{l}\text { Process- } \\
\text { product }\end{array}$ & 15 & 3.980 & 5.821 & 1.50301 & 36.5764 & 43.0236 & 33.00 & 55.00 \\
\hline Product & 15 & 3.666 & 4.670 & 1.20581 & 34.0805 & 39.2529 & 32.00 & 47.00 \\
\hline Total & 45 & 3.815 & 5.680 & .84683 & 36.4489 & 39.8622 & 26.00 & 55.00 \\
\hline
\end{tabular}

Table 2 demonstrates the results of One-Way ANOVA ran for the purpose of comparing the mean scores of the three groups in OPT.

Table 2. Results of one-way ANOVA for OPT

\begin{tabular}{lccccc}
\hline scores & $\begin{array}{c}\text { Sum of } \\
\text { Squares }\end{array}$ & df & $\begin{array}{c}\text { Mean } \\
\text { Square }\end{array}$ & F & Sig. \\
\hline $\begin{array}{l}\text { Between } \\
\text { Groups }\end{array}$ & 74.178 & 2 & 37.089 & 1.158 & .324 \\
$\begin{array}{l}\text { Within } \\
\text { Groups }\end{array}$ & 1345.733 & 42 & 32.041 & & \\
Total & 1419.911 & 44 & & & \\
\hline
\end{tabular}

As is shown in the table, considering the alpha level of .05 the $p$-value $(p=.324)$ is greater than our assumed alpha level, and this result indicates that the three groups were homogeneous in terms of their English language proficiency in the outset of the study.

Using the primary trait rubric each learner was given a score out of 25 . Table 3 shows the descriptive statistics for the scores of the students in each of the three groups. The statistics include mean, standard deviation, and standard error of the means regarding the performance of the participants in each group, separately. 
Table3. Descriptive statistics for rhetorical organization in the post-test

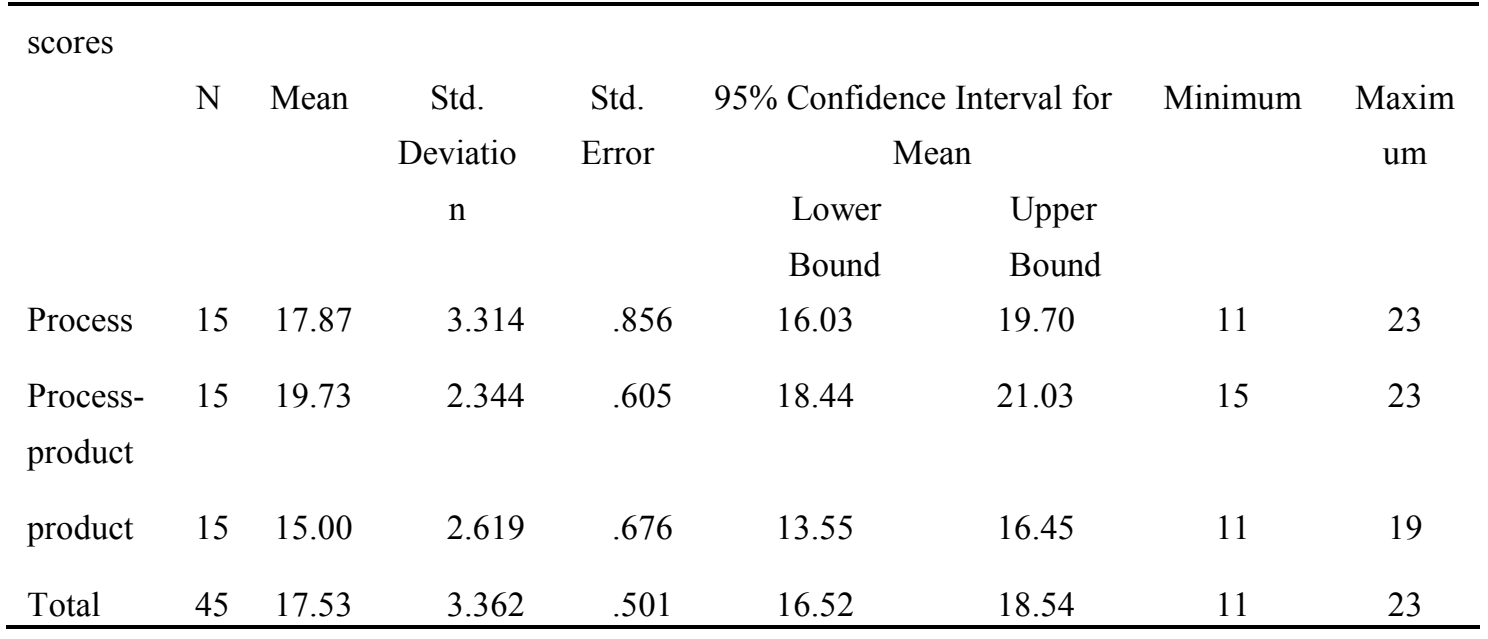

As the main aim of the study was to compare three mean scores from the three participating groups of EFL learners, One-way ANOVA was used for the statistical analysis of the data .Table 4 demonstrates the results of ANOVA test for the comparison of groups regarding the rhetorical organization of their essays.

Table 4. Results of ANOVA test for writing rhetorical organization of argumentative essays

\begin{tabular}{lllllll}
\hline scores & Sum of & df & $\begin{array}{c}\text { Mean } \\
\text { Square }\end{array}$ & F & Sig. \\
& Squares & & & \\
Between & 170.533 & 2 & 85.267 & 1.096 & .000 \\
Groups & 326.667 & 42 & 7.778 & & \\
Within & & & & & \\
Groups & 497.200 & 44 & & & \\
\hline Total & & & & & \\
\hline
\end{tabular}

As is shown in the table a One-way analysis of variance indicated that there was a significant difference in the rhetorical organization of essays written in the groups taught based on process approach $(\mathrm{M}=17.87, \mathrm{SD}=3.314)$ and processproduct approach $(\mathrm{M}=19.78, \mathrm{SD}=2.344)$ and product approach to writing $(\mathrm{M}=15.00, \mathrm{SD}=2.619), \mathrm{F}(2,42)=1.096$, $\mathrm{p}<.05$.

Table 5 shows the result of the Student-Newman-Keuls post-hoc test.

Table5. Results of the post-hoc test

\begin{tabular}{lccc}
\hline & \multicolumn{3}{c}{ Subset for alpha $=0.05$} \\
\cline { 3 - 4 } groups & $\mathrm{N}$ & 1 & 2 \\
\hline 3 & 15 & 15.00 & \\
1 & 15 & & 17.87 \\
2 & 15 & & 19.73 \\
Sig. & & 1.000 & .074 \\
\hline
\end{tabular}

Note. Means for groups in homogeneous subsets are displayed.

The results of S-N-K post hoc tests illustrate that the students who wrote based on either process approach or processproduct approach were more successful in their application of argumentative essays' rhetorical organization than those 
learners who wrote on the basis of product approach to writing. However, the table shows no significant difference in the performance of the two groups writing based on process or process-product approaches, as the p-value demonstrated in the table is greater than our assumed alpha level $(\mathrm{p}=.074)$.

\section{Discussion and conclusion}

This study was an attempt to discover if any of the three approaches to teaching writing to EFL learners including Process approach, Process-product, and Product approaches has any impact on the rhetorical organization of the argumentative essays produced by the learners. To this end 45 EFL intermediate EFL learners were randomly divided into three groups each being taught how to write an argumentative essay based on one of the aforementioned instructional approaches. After the instruction which lasted for six sessions, the rhetorical organization of the learners' argumentative essays was analyzed based on their performance on a post-test using a rubric adopted from the study of Tsai (2006).

Overall, it can be concluded from the analysis of the results via One-way ANOVA that learners who wrote on the basis of process approach while going through different stages of planning, drafting, revising, or editing and also those learners who practiced writing via process-product approach to writing did better with regard to the rhetorical organization of their argumentative essays compared with those who were taught according to the traditional product approach, and our null hypothesis can be rejected. To put it more specifically, the students who were taught based on the process approach to writing gained a mean score of 17.87 and those who received instruction on the basis of process-product approach obtained a mean of 19.73 for their performance regarding the rhetorical organization of their argumentative essays, while those in the group taught through product approach gained the mean score of 15 . Comparing the three mean scores via One-way ANOVA at the alpha level of 0.05 demonstrated a p-value of .000 which indicates a significant difference among the three groups. Moreover, the results of the post-hoc test indicated that the groups who were taught using either process or process-product approaches outperformed the product-based group. However, no statistically significant difference was found between the groups taught based on these two approaches to writing $(\mathrm{p}=.074)$. Thus, the findings indicate that by giving credence to the different stages of writing or combining the stages of the process writing with the benefits of model essays, there is a better opportunity for EFL learners to improve their skills in producing rhetorically acceptable argumentations. In other words, with using process approach to writing with its emphasis on the how of writing students are provided with the opportunity to become deeply familiar with different aspects of an argumentative essay. One of these aspects which was the focus of the present study is the rhetorical organization of argumentative writing. The findings also revealed that using process-product approach is conducive to a better organization of the argumentative essay. Process-product approach makes the students aware of the specific organization of the essay in its first stage by drawing learners' attention to the model essay, and thus it boosts the act of writing. These findings are in line with the results of previous studies which indicated the benefits of an integrated approach such as Tangpermpoon (2008) or Gholami Pasand and Bazarmaj Haghi (2013). Accordingly, the results of this study can be useful for both EFL learners and teachers who look for appropriate ways of making the learners progress in their writing skills, especially the rhetorical organization of their essays.

As the present study only focused on a limited number of learners in each group and since they were all at the intermediate level of English proficiency, more extended studies involving more participants at other proficiency levels can be further conducted to increase our knowledge in these areas. In addition, further studies can investigate the impact of these instructional approaches on other dimension of writing skill including, content, accuracy, complexity, or fluency of EFL writing. Finally, further research is needed to be conducted to explore whether other genres such as narrative or expository writing can make any difference in the findings of the study.

\section{References}

Badger, R. \& White, G. (2000). “A process genre approach to teaching writing”. ELT Journal 54(2): 153-160.

Cheng, F. W. \& Chen, Y. M. (2009). Taiwanese argumentation skills: Contrastive rhetoric perspective. Taiwan International ESP Journal, 1(1), 23-50.

Fishman, S. \& McCarthy, L. (2001). An ESL writer and her discipline-based professor, Written Communication, 18, 180-228.

Freedman, A. (1987). Learning to write again, Carleton Papers in Applied Language Studies, 4, 95-116.

Freedman, A. (1993). Show and tell? The role of explicit teaching in the learning of new genres, Research in the Teaching of English, 27, 222-251.

Gholami Pasand, P. \& Bazarmaj Haghi, E. (2013). Process-Product Approach to Writing: the Effect of Model Essays on EFL Learners' Writing Accuracy. IJALEL, 2(1), 75-79.

Hyland, K. 2003. Genre-based pedagogies: A social response to process. Journal of Second Language Writing, 12: 1729.

Jarunthawatchai, W. (2010). A process-genre approach to teaching second language writing: theoretical perspective and implementation in a Thai university setting. An unpublished Ph.D. dissertation. University of Southampton, faculty of law, arts \& social sciences, school of humanities. England. 
Kang, J. (2005). Written narratives as an index of L2 competence in Korean EFL learners. Journal of Second Language Writing, 14(4), 259-279.

Khiabani, M.N. \& Pourghassemian, H. (2009). Transfer of 11 organizational patterns in argumentative writings of Iranian EFL students: Implications for contrastive rhetoric. Journal of Teaching English as a Foreign Language and Literature, 1(4), 23-38.

Matsuda P. K. (2003). Second language writing in the twentieth century: A situated historical perspective. In Kroll (Ed.) Exploring the dynamics of second language writing. Cambridge: Cambridge University Press.

McCann, T. M. (1989). Student argumentative writing: Knowledge and ability at three grade levels. Research in the Teaching of English, 23, 62-76.

$\mathrm{Mu}$, C. \& Carrington, S. (2007). An investigation of three Chinese students' English writing strategies. TESL-EJ, 11(1), 1-23. Available: http://tesl-ej.org/ej41/a1.html.

Myles, J. (2002). Second language writing and research: the writing process and error analysis in student texts. TESLEJ, $6(2)$.

Nunan, D. (1999). Second Language Teaching and Learning. U.S.: Heinle \& Heinle.

Richards J. C. \& Renandya, W. A. (2002). Methodology in language teaching: An anthology of current practice. Cambridge, UK: Cambridge University Press. Schmitt, N. (2002). An Introduction to Applied Linguistics. (Ed.). London: Arnold \& Oxford University Press.

Sutikno, M.K. (2008). Responding to students' writing. (Teaching writing or assessing it?). Journal Pendidikan Penabur, 10(7), 51-59.

Tangpermpoon, T. (2008). Integrated approaches to improve students' writing skills for English major students. $A B A C$ Journal, 28 (2), 1-9.

Toulmin, S. E. (1958). The uses of argument. Cambridge, UK: Cambridge University Press.

Torghabeh, R.A., Hashemi, M.R., \& Ahmadi, H, Sh. (2010). Writing through literature: a novel approach to EFL writing instruction. Iranian EFL Journal, 6(4), 7-23.

Tribble, C. (1990). Writing. Oxford: Oxford University Press.

Tsai, Y. C. (2006). The effects of asynchronous peer review on university students' argumentative writing. (unpublished doctoral dissertation). University of Maryland, Maryland, U.S.

Zare-ee, A, \& Farvardin, M. T. (2009). Comparison of university level EFL learners' linguistic and rhetorical patterns as reflected in their 11 and 12 writing. Novitas-ROYAL, 3(2), 143-155.

\section{Appendix}

Primary Traits: Scoring Guide for Toulmin's Criteria for Argumentation

\section{Claim}

6 Clear, complete generalizations related to the proposition are stated.

4 The reader must infer the writer's intent from information given by the writer, but enough information is given so that generalizations are related to the proposition or topic.

2 The writer's assertions are unclear and lack specificity although the generalizations are related to the proposition or topic.

0 There is no claim related to the proposition or topic.

\section{Data}

6 The writer gives supporting data that is complete, accurate, and related to the proposition.

4 The writer gives supporting data that is related to the proposition, but not complete. The reader must infer much from the data.

2 The writer offers weak, inaccurate, or incomplete data.

0 The writer either offers no data or offers data having no relevance to the claim.

\section{Opposition}

6 There is a systematic identification of the opposition.

4 There is an identification of opposing arguments, but these arguments are not specific.

2 There is some offering of opposition, but it is not specific.

0 There is no recognition of opposition offered.

\section{Refutation}

6 There is systematic identification of the opposition and the opposing arguments.

4 Counter arguments are present, but the reader must provide the link between the counter arguments and the specific opposition.

2 There is a vague reference to implied opposition or a weak denial of opposition claims.

0 There is no offering of response to counter arguments.

\section{Qualifier}

1 Qualifier explicitly stated

0 No qualifier explicitly stated 